\title{
E-Promosi untuk Komunikasi Pelanggan di Sektor Minuman: Studi Kopi Kenangan
}

\author{
Eva Rachmawati $^{\left.1^{*}, 4\right)}$, Ratih Hurriyati ${ }^{2}$, Puspo Dewi Dirgantari ${ }^{3}$ \\ ${ }^{1 * 2,3)}$ Ilmu Manajemen, Universitas Pendidikan Indonesia Bandung \\ 4) Manajemen, Universitas Sangga Buana Bandung \\ Jawa Barat, Indonesia, 40154 \\ E-mail: evarachmawati44@ gmail.com ${ }^{\left.{ }^{*}\right)}$
}

\begin{abstract}
ABSTRAK
E-promotion pada media sosial dapat mempengaruhi keputusan pembelian di Kopi Kenangan. Variabel yang diteliti yakni personal relevance $\left(\mathrm{X}_{1}\right)$, interactivity $\left(\mathrm{X}_{2}\right)$, message $\left(\mathrm{X}_{3}\right)$, dan variabel keputusan pembelian pada konsumen kopi kenangan menggunakan model AIDA. Penelitian ini menggunakan sebanyak 165 responden. Penelitian ini dilakukan dengan penelitian secara deskriptif dan verifikatif melalui metode non probality sampling. Adapun teknik sampel yang diambil dengan cara accidental sampling, yaitu cara untuk mendapatkan sampel berdasarkan konsumen yang kebetulan bertemu pada saat melakukan penelitian. Kemudian untuk menguji instrumen penelitian dengan uji validitas dan uji realibilitas. Lalu data dianalisis menggunakan regresi berganda, hasilnya menyatakan personal relevance $\left(\mathrm{X}_{1}\right)$ memberikan pengaruh terhadap keputusan pembelian (Y) Kopi Kenangan. Interactive $\left(\mathrm{X}_{2}\right)$ tidak memberikan pengaruh terhadap keputusan pembelian Kopi Kenangan. Sedangkan message $\left(\mathrm{X}_{3}\right)$ memberikan pengaruh terhadap keputusan pembelian Kopi Kenangan. Variabel yang memberikan pengaruh besar terhadap keputusan pembelian (Y) adalah variabel personal relevance.
\end{abstract}

Kata kunci: E-Promotion; Personal Relevance; Interactivity; Message

\begin{abstract}
E-promotion on social media can influence purchasing decisions at Kopi Kenangan. The variables studied were personal relevance $\left(X_{1}\right)$, interactivity $\left(X_{2}\right)$, message $\left(X_{3}\right)$, and purchase decision variables for Kopi Kenangan consumers using the AIDA model. This study used 165 respondents. This research was conducted with descriptive research and verification through non-probability sampling methods. The sampling technique is taken by accidental sampling, a way to get a sample based on consumers who happen to meet while doing research. Then to test the research instrument with a validity test and reliability test. The data were then analyzed using multiple regression; the results stated that Personal Relevance $\left(X_{1}\right)$ influenced purchasing decision ( $Y$ ) for Coffee Memories. Interactive $\left(X_{2}\right)$ does not influence the Coffee Memories purchase decision. In contrast, Message ( $\left.X_{3}\right)$ influences the Coffee Memories purchase decision. The variable that has a big influence on the purchase decision $(Y)$ is the personal relevance variable.
\end{abstract}

Keyword: E-Promotion; Personal Relevance; Interactivity; Message 


\section{PENDAHULUAN}

Kebutuhan manusia terhadap teknologi sudah tidak dapat dipungkiri keberadaannya. Hal ini dikarenakan teknologi sudah melekat menjadi kebutuhan manusia, maka tak ayal banyaknya teknologi baru yang bermunculan yang mampu menjawab segala yang menjadi kebutuhan manusia pada sehari-hari. Terlebih pada teknologi di bidang informasi dan komunikasi, yang mana berkembang sangat pesat, minimal pada beberapa akhir dekade ini. (Alfirahmi, 2019). Kopi merupakan minuman yang sedang viral dan di anggap minuman kekinian. Menu kopi sudah ada dari jaman sebelumnya hanya yang membedakan adalah konsep yang disajikan. Sekarang ini semua sudah bisa terkoneksi dengan internet sehingga pemesanan kopi pun bisa dengan menggunakan app. Anak milenial baik laki-laki ataupun perempuan saat ini selalu nongkrong di tempat kopi yang pada akhirnya kedai kopi mulai menjamur. Ditambah adanya e-promotion sehingga dapat terjangkau oleh konsumen. Kami memiliki begitu banyak teori daring tentang perilaku konsumen yaitu Teori Konfirmasi Harapan, Teori Difusi Inovatif, Model Penerimaan Teknologi, Teori Perilaku Berencana, Teori Reasoned Action (Shaupp and Blanger, 2005).

Strategi dalam memasarkan produk sangatlah dibutuhkan oleh perusahaan, seperti melalui metode promosi yang menyasar langsung pada bagaimana perilaku konsumen di pasar, sehingga diharapkan mampu memberikan minat yang baik bagi konsumen. Apabila perusahaan dapat melakukan hal tersebut maka memungkinkan perusahaan mendapatkan keuntungan yang lebih dari pesaing (Asshidieqi, 2012).

Persaingan pasar sedang terjadi di bidang bisnis cukup ketat sehingga para pembisnis harus pintar untuk mempromosikan produknya karena secara tidak langsung akan mempengaruhi pangsa pasarnya. Hal yang paling utama perusahaan dapat memuaskan kebutuhan dan keinginan konsumen dalam memilih dan menggunakan jasa yang kita tawarkan (Kottler dan Armstrong, 2008).

Perilaku seseorang terhadap iklan dipengaruhi oleh personal relevance dari penelitian yang dilakukan Claypool el al.(2004), yang mana hal tersebut berdampak pada bagaimana seseorang merubah point of view dalam mengambil sebuah keputusan. Coyle and Thorson (2001); Juang and Benbasat (2003); Liu and Shrum (2002).

Selain itu, persepsi seseorang dalam menilai sebuah iklan yang disajikan pada media masa juga dipengaruhi oleh interactivity. Hal tersebut diakibatkan karena pesan yang disampaikan mampu menarik perhatian konsumen. Maka tak jarang, banyak iklan yang memiliki nilai aestetik dan entertainment dibuat agar menarik perhartian calon pembeli. 
Sebagaimana Gordon dan Delima (1997) yang memaparkan bahwa iklan komersial memiliki fokus pada pesan informasi, yang mana hal tersebut harus sampai pada konsumen. Beberapa penelitian menggunakan objek lebih ke perusahaan jasa sedangkan yang membedakan penelitian ini adalah non jasa sehingga jelas memiliki perbedaan yang signifikan. Edward Tirtanata dan James Prananto merupakan pendiri "Kopi Kenangan” pada tahun 2017. Usaha Kopi merupakan usaha yang sedang menjamur di Kota Bandung. Salah satu yang kopi yang sedang marak dibicarakan masyarakat adalah "Kopi Kenangan" dimana kopi tersebut memberikan citra rasa yang berbeda. Pengusaha kopi tersebut memiliki tantangan untuk dapat menarik konsumen dengan mengadakan promosi. Promosi yang cepat yaitu dengan menggunakan e-promotion karena zaman sudah berubah menjadi zaman milenial. Kopi Kenangan memperkenalkan aplikasi bagi para penggemar kopi. Dalam aplikasi disediakan layanan pembelian, pembayaran dan pencarian kedai kopi terdekat.

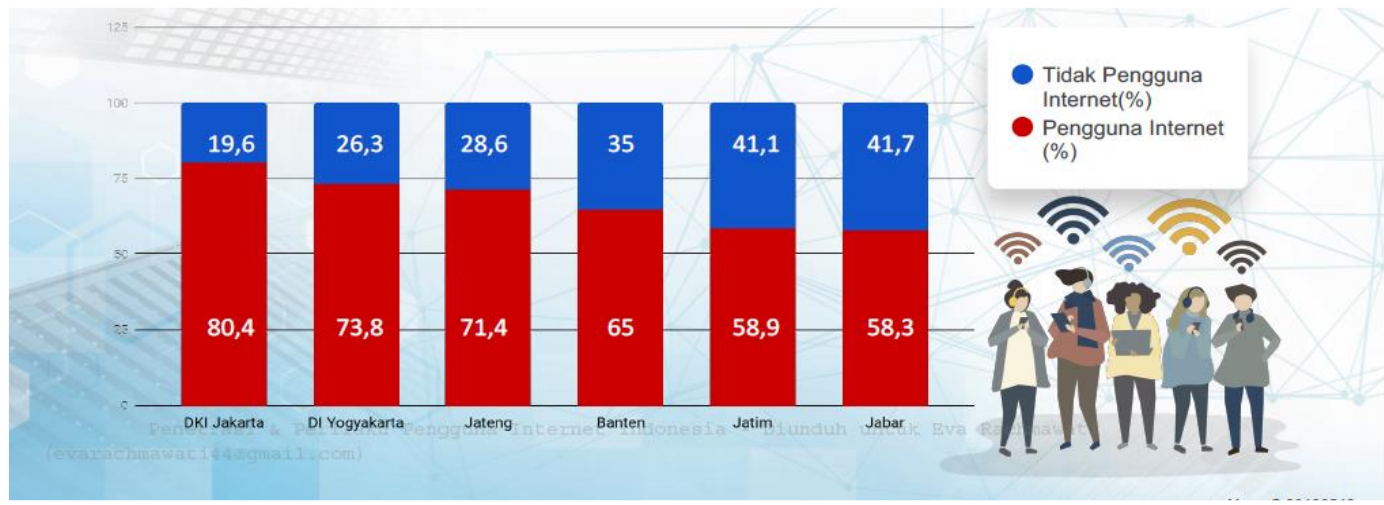

Gambar 1. Persentasi Pengguna Internet di Jawa Barat

Sumber: Penetrasi Pengguna Internet di Setiap Provinsi Wilayah Jawa dari Jumlah Penduduk di Setiap Provinsi APJII 2018

Dari data diatas menyatakan bahwa pengguna internet untuk Jawa Barat sebesar 58,3\% sehingga masyarakat sudah terbiasa dengan menggunakan internet atau jejaring sosial.

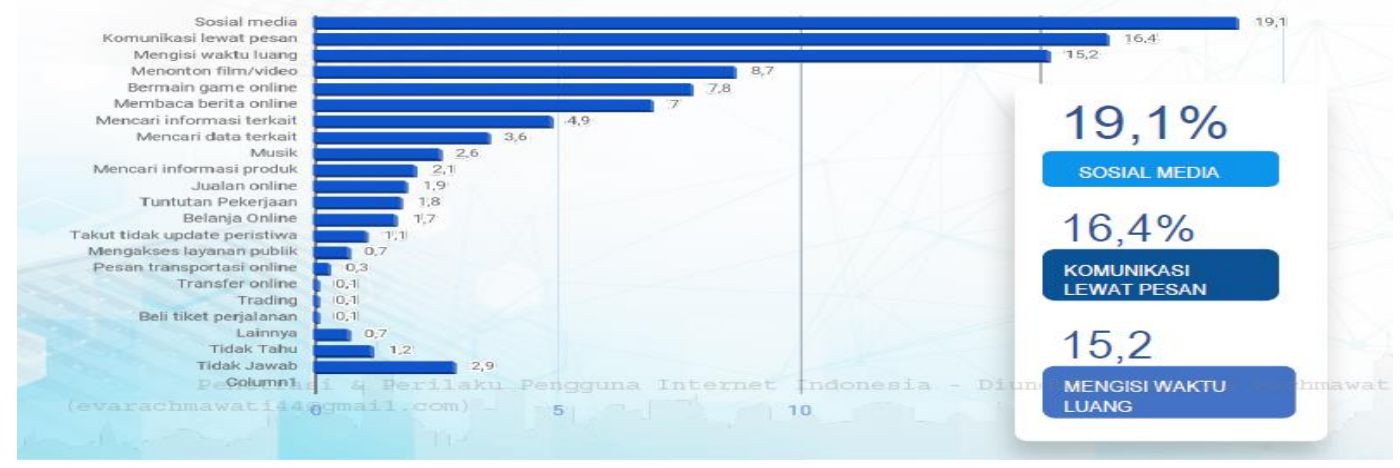

Gambar 2. Penyelengaran Jasa Internet

Sumber: Hasil Survei 2018 APJII 
Sedangkan pada Gambar 2. menjelaskan bahwa pengguna media sosial sebesar 19,1\%, berkomunikasi melalui pesan sebanyak $16,4 \%$ dan untuk belanja online sebesar 1,7\% sehingga menyatakan bahwa masyarakat lebih sering melihat promosi di media social. Dikutip dalam Wikipedia (13/02/2020) seiring perkembangan zaman yang serba digital ini sejarah kopi kenangan sangat yang pada mulanya tidak menggunakan aplikasi sekarang menggunakan aplikasi untuk memudahkan konsumen untuk bertransaksi dan menikmati menu kopi yang disediakan kopi kenangan. Baginya dalam menciptakan teknologi sendiri adalah salah satu kesuksesan yang diraih sebuah perusahaan untuk dapat memasarkan produknya. Kemajuan teknologi itu penting sebagai langkah awal contoh kita main lewat Instagram, kemudian kita bisa berkembang dengan adanya online delivery (Edward, 2020). Adapun penelitian ini dilakukan bertujuan: (1) untuk mengetahui personal relevance secara signifikan mempengaruhi keputusan pembelian di Kopi Kenangan (2) untuk mengetahui interactive secara signifikan memberikan pengaruh terhadap keputusan pembelian Kopi Kenangan (3) untuk mengetahui message berpengaruh signifikan pada keputusan pembelian Kopi Kenangan, dan (4) untuk mengetahui personal relevance, interactive serta message berpengaruh secara signifikan terhadap keputusan pembelian Kopi Kenangan.

E-promotion merupakan strategi dengan menggunakan media internet dalam melakukan promosi secara online, yang terbagi pada tiga bagian yakni promosi produk dan jasa, website dan domain, hal tersebut yang akan mempengaruhi terhadap keputusan pembelian.

E-promotion yang sering digunakan diantaranya adalah instagram, facebook, dan twitter (Arwiedya, 2011; Jamaludin, 2015). Penggunaan Internet telah mengarah dan menciptakan banyak peluang pemasaran dan meningkatkan efektivitas dan efisiensi strategi pemasaran yang tercermin melalui penggunaan teknik, metode, dan praktik e-promotion untuk memenuhi kebutuhan konsumen. Perilaku belanja online memiliki hubungan langsung dengan lima elemen ini seperti: toko elektronik, logistik dukungan, karakteristik produk, karakteristik teknologi situs web, karakteristik informasi dan rumah presentasi halaman. Menurut penelitian,yang memiliki gaya hidup kabel dan yang memiliki keterbatasan waktu, menghabiskan lebih sedikit waktu untuk membeli barang secara online (Shewan and Stokes, 2013).

Promosi memiliki indikator diantaranya adalah iklan, penjualan pribadi, promosi penjualan dan publisitas (Kottler dan Armstrong, 2008). Selain itu Kotler menambahkan bahwa terjangkaunya harga disesuaikan dengan daya saing harga, kualitas produk yang dipasarkan, serta manfaat yang diperoleh (Kotler dan Amstrong, 2012).

Berdasarkan hasil penelitian Claypool et al. (2004) yang disarikan oleh Campbell and 
Wright, 2008) bahwa perilaku seseorang dalam mengambil sebuah keputusan dapat dipengaruhi oleh bagaimana produk tersebut memiliki tingkat personal relevance pada konsumen. Hal ini berarti bahwa personal relevance memiliki dampak terhadap individu. Selain itu, persepsi seseorang dalam menilai sebuah iklan di media massa dipengaruhi juga oleh interactivity di dalamnya (Coyle and Thorson, 2001; Juang and Benbasat, 2003; Liu and Shrum, 2002; dikutip dari Campbell and Wright, 2008). Pesan yang mengandung nilai entertainment terbukti mampu menarik perhatian konsumen, sebab pesan yang bersifat komersial tersebut memiliki fokus pada penyampaian informasi (Gordon dan Delima, 1997).

Metode pengintegrasian yang mengkombinasikan pemahaman dalam keputusan konsumen merupakan salah satu alternatif atau lebih untuk menentukan salah satu diantaranya (Sangadji, 2013). Menurut Kotler dan Keller (2009), ada beberapa tahap yang pelanggan diantaranya: pengenalan masalah, proses menggali informasi, penilaian secara alternatif, menetapkan pembelian, dan proses setelah pembelian.

Kotler menambahkan bahwa perencanaan dalam pembelanjaan serta hasil dari pembelian tergantung pada perilaku seseorang yang mampu meminimalisir alternatif yang disukai, hal tersebut berkaitan pada kedua hal, (1) sejauh mana perilaku negatif pembeli pada opsi yang disukai, dan (2) seberapa kuat dorongan pembeli agar mengikuti apa yang diinginkan orang, hal ini berkaitan erat pada kondisi yang mungkin tidak dapat diantisipasi.

Swastha dan Handoko (2011) memaparkan bahwa ketika mengambil keputusan dalam membeli produk sebenarnya terdiri dari gabungan berbagai keputusan. Struktur inilah yang kemudian mendorong dalam menentukan keperluan dan memiliki keinginan untuk memiliiki sebuah produk tertentu, yang diharapkan menimbulkan keputusan yakin akan membeli bagi konsumen. Hal ini diukur dari bagaimana produk yang dipilih, merek, penyalur, waktu membeli, jumlah pembelian dan metode dalam melakukan pembayaran (Kotler dan Armstrong, 2016). Yang mana tahapan dalam memutuskan untuk melakukan pembelian adalah dari mulai pengenalan terhadap masalah, kemudian memeriksa informasi, mengevaluasi dengan alternatif, memutuskan untuk membeli dan perlakuan setelah membeli (Kotler dan Keller, 2009).

Menurut Kotler keputusan dalam membeli produk pada konsumen yakni melalui tahap proses secara actual melakukan pembelian produk (Kotler dan Amstrong, 2003). Sedangkan Nugroho (2003) mengartikan adanya proses gabungan yang berasosiasi pada ranah sikap pengetahuan dalam menilai dua atau lebih perilaku alternatif lalu kemudian memilih salah satunya. Senada dengan Schiffman dan Kanuk (Musay, 2013) bahwa keputusan pembelian adalah pemilihan terhadap dua alternatif yang ada. Oleh karena itu, ketika seseorang membuat 
suatu keputusan harus memiliki alternatif yang akan dipilih.

Sementara itu Wijaya (2011) memaparkan langkah-langkah yang dilakukan oleh konsumen dalam menanggapi sebuah iklan, yang kemudian ia sebut sebagai model AIDA (Attention, Interest, Desire, dan Action). Iklan tersebut seyogyanya menyita perhatian konsumen, lalu mampu mempertahankan minat konsumen, kemudian merangsang keinginan konsumen dalam memiliki produk hingga melakukan pembelian suatu produk.

\section{METODE PENELITIAN}

Penelitian ini menggunakan metode deskriptif dan verifikatif. Pengukuran sampel yakni tahapan dalam memilih besarnya sampel yang dilakukan dalam penelitian. Teknik sampling yang digunakan adalah non probality sampling (Kusmayadi, 2004). Dalam penelitian ini pengambilan sampel ditetapkan secara quota sampling, sampel yang digunakan sebanyak 165 orang konsumen dimana yang di tujuan bagi para konsumen kopi kenangan. Sedangkan pada teknik pengambilan sampel melalui accidental sampling, yakni pengambilan sampel yang dilakukan secara kebetulan dengan konsumen.

Tabel 1. Operasionalisasi Variabel

\begin{tabular}{|c|c|c|c|c|}
\hline Variabel & Dimensi & Indikator & Skala Ukur & Item \\
\hline \multirow[t]{9}{*}{ E-Promotion } & Personal & Initiative & Ordinal & 1 \\
\hline & Relevance & Social network & & 2 \\
\hline & & Relationship & & 3 \\
\hline & Interactivity & Komunikasi & Ordinal & 1 \\
\hline & & Insteraksi & & 2 \\
\hline & & $\begin{array}{l}\text { Format informasi yang } \\
\text { menarik }\end{array}$ & & 3 \\
\hline & Message & Kemudahan akses & Ordinal & 1 \\
\hline & & Informasi lengkap & & 2 \\
\hline & & Informasi menarik & & 3 \\
\hline \multirow{10}{*}{$\begin{array}{l}\text { Keputusan } \\
\text { Pembelian }\end{array}$} & Attention & Pesan yang disampaikam & Ordinal & 1 \\
\hline & & Penayangan & & 2 \\
\hline & & Produk dalam promosi iklan & & 3 \\
\hline & Interest & Media yang di gunakan & Ordinal & 4 \\
\hline & & Persefektif konsumen & & 5 \\
\hline & & Kejelasan & & 6 \\
\hline & Desire & Kepercayaan konsumen & Ordinal & 7 \\
\hline & & Minat konsumen & & 8 \\
\hline & Action & Keyakinan untuk membeli & Ordinal & 9 \\
\hline & & Kesesuaian produk & & 10 \\
\hline
\end{tabular}




\section{HASIL DAN PEMBAHASAN}

\section{Tabel 2. Coefficients ${ }^{\mathrm{a}}$}

\begin{tabular}{|c|c|c|c|c|c|c|c|}
\hline \multirow[b]{2}{*}{ Model } & \multicolumn{2}{|c|}{$\begin{array}{l}\text { Unstandardized } \\
\text { Coefficients }\end{array}$} & \multirow{2}{*}{$\begin{array}{c}\begin{array}{c}\text { Standardized } \\
\text { Coefficients }\end{array} \\
\text { Beta }\end{array}$} & \multirow[b]{2}{*}{$\mathbf{t}$} & \multirow[b]{2}{*}{ Sig. } & \multicolumn{2}{|c|}{ Collinearity Statistics } \\
\hline & B & Std. Error & & & & Tolerance & VIF \\
\hline 1 (Constant) & 10.126 & .078 & & 130.098 & .000 & & \\
\hline $\begin{array}{l}\text { Personal } \\
\text { Relevance }\end{array}$ & 1.012 & .028 & 1.003 & 36.030 & .000 & .133 & 7.495 \\
\hline Interactive & .012 & .028 & .012 & .441 & .660 & .139 & 7.216 \\
\hline Message & -.035 & .014 & -.034 & -2.509 & .013 & .550 & 1.820 \\
\hline
\end{tabular}

Tabel di atas menggambarkan perolehan bentuk pada peramaan regresi linier berganda, selengkapnya sebagai berikut:

$$
\mathrm{Y}=10,126+1,012 \mathrm{X}_{1}+0,12 \mathrm{X}_{2}-0,35 \mathrm{X}_{3}
$$

Nilai pada koefisien regresi pada variabel bebas ini menyatakan bahwa jika variabel bebas meningkat sebesar satu satuan serta nilai variabel bebas yang lainnya konstan, maka nilai pada variabel terikat diperkirakan dapat meningkat atau dapat pula turun disesuaikan dengan tanda koefisien regresi pada variabel bebas.

Adapun nilai konstanta yang diperoleh sebesar 10,126. Hal ini berarti variabel terikat (Y) tidak dipengaruhi oleh ketiga variabel bebas personal relevance $\left(\mathrm{X}_{1}\right)$, interactivity $\left(\mathrm{X}_{2}\right)$, message $\left(\mathrm{X}_{3}\right)$ bernilai nol. Berdasarkan hal tersebut maka besarnya rata-rata keputusan pembelian konsumen bernilai 10,126.

Sedangkan koefisien regresi pada variabel bebas menggambarkan arah hubungan dari variabel yang terkait dengan keputusan pembelian konsumen (Y). Sebab koefisien regresi variabel $\mathrm{X}_{1}$ bernilai positif, maka hal ini menunjukkan hadirnya hubungan yang searah antara personal relevance dengan keputusan pembelian konsumen dengan koefisien regresi sebesar 1,012 yang mana untuk setiap pertambahan pada personal relevance.

Begitupula dengan koefisien regresi pada variabel bebas $\mathrm{X}_{2}$ yang memiliki nilai positif, hal ini ditunjukkan dengan adanya hubungan searah antara interactivity $\left(\mathrm{X}_{2}\right)$ dengan keputusan pembelian konsumen (Y). Adapun nilai koefisien regresi variabel $\mathrm{X}_{2}$ sebesar 0,12 , yang berarti bahwa setiap pertambahan interactivity sebesar satu satuan akan meningkatkan keputusan pembelian konsumen pula sebesar 0,12.

Sementara itu pada variabel $\mathrm{X}_{3}$ nilai koefisien regresinya negatif, sebesar 0,35 . Hal ini mengindikasikan apabila message $\left(\mathrm{X}_{3}\right)$ bertambah sebesar satu satuan maka akan menguangi 
keputusan pembelian konsumen (Y) sebesar 0,35.

Tabel 3. Model Summary ${ }^{b}$

\begin{tabular}{llclcc}
\hline Model & R & R Square & $\begin{array}{l}\text { Adjusted } \\
\text { Square }\end{array}$ & $\begin{array}{c}\text { R Std. Error of } \\
\text { Estimate }\end{array}$ & $\begin{array}{c}\text { the Durbin- } \\
\text { Watson }\end{array}$ \\
\hline 1 & $.992^{\mathrm{a}}$ & .983 & .983 & .129797 & 1.773 \\
\hline
\end{tabular}

a. Predictors: (Constant), Message, Interactive, Personal Relevance

b. Dependent Variable: Keputusan Pembelian

Adapun besarnya pengaruh antara variabel bebas terhadap variabel terikat dalam penelitian ini dapat ditunjukkan oleh koefisien determinasi dengan rumus sebagai berikut :

$$
\begin{aligned}
\mathrm{KD} & =\mathrm{R}^{2} \times 100 \% \\
& =(0,992)^{2} \times 100 \% \\
& =99,2 \%
\end{aligned}
$$

Hal di atas menunjukkan bahwa pada ketiga variabel bebas berpengaruh sebesar 99,2\% pada keputusan pembelian konsumen $(\mathrm{Y})$. Yang mana sisanya $(0,8 \%)$ merupakan kontribusi dari variabel lain.

Pengaruh parsial perlu dianalisis agar dapat mengetahui seberapa kuat pengaruh pada

\begin{tabular}{|c|c|c|c|c|c|c|c|}
\hline \multirow[b]{2}{*}{ Model } & \multicolumn{2}{|c|}{$\begin{array}{l}\text { Unstandardized } \\
\text { Coefficients }\end{array}$} & \multirow{2}{*}{$\begin{array}{c}\begin{array}{c}\text { Standardized } \\
\text { Coefficients }\end{array} \\
\text { Beta }\end{array}$} & \multirow[b]{2}{*}{$\mathbf{t}$} & \multirow[b]{2}{*}{ Sig. } & \multicolumn{2}{|c|}{ Collinearity Statistics } \\
\hline & $\mathbf{B}$ & Std. Error & & & & Tolerance & VIF \\
\hline 1 (Constant) & 10.126 & .078 & & 130.098 & .000 & & \\
\hline $\begin{array}{l}\text { Personal } \\
\text { Relevance }\end{array}$ & 1.012 & .028 & 1.003 & 36.030 & .000 & .133 & 7.495 \\
\hline Interactive & .012 & .028 & .012 & .441 & .660 & .139 & 7.216 \\
\hline Message & -.035 & .014 & -.034 & -2.509 & .013 & .550 & 1.820 \\
\hline
\end{tabular}
tiap variabel bebas dengan variabel terikat, yang ditunjukkan pada tabel berikut:

\section{Tabel 4. Coefficients ${ }^{\mathrm{a}}$}

b. Dependent Variable: Keputusan Pembelian

\begin{tabular}{ccccc}
\cline { 2 - 4 } Model & $\begin{array}{l}\text { Unstandardized } \\
\text { Coefficients }\end{array}$ & $\begin{array}{l}\text { Standardized } \\
\text { Coefficients }\end{array}$ & Besar Pengaruh Secara Parsial \\
\cline { 2 - 4 } & $\mathbf{B}$ & Std. Error & Beta & \\
\hline $\begin{array}{c}\text { Personal } \\
\text { Relevance }\end{array}$ & 1.012 & .028 & 1.003 & 99,39 \\
Interactive & .012 & .028 & .012 & 1,104 \\
Message & -.035 & .014 & -.034 & -2.17 \\
Pengaruh Total & & & & 98,32 \\
\hline
\end{tabular}

Sumber:data yang diolah 
Tabel 4 menunjukkan besarnya pengaruh antara variabel bebas terhadap variabel terikat secara parsial. Dengan rincian pada personal relevance $\left(\mathrm{X}_{1}\right)$ terhadap variabel terikat secara parsial sebesar $99,39 \%$, serta pengaruh interactivity $\left(\mathrm{X}_{2}\right)$ terhadap variabel terikat secara parsial sebesar $1,104 \%$, dan pengaruh message $\left(\mathrm{X}_{3}\right)$ terhadap variabel terikat secara parsial sebesar $-2,17 \%$. Oleh karena itu, jumlah keseluruhan antara variabel bebas terhadap variabel terikat secara bersamaan adalah sebesar $98,32 \%$. Yang mana dapat dilihat juga pada nilai koefisien determinasi yang diperoleh.

Dari tabel, uji t menunjukan bahwa variabel personal relevance $\left(\mathrm{X}_{1}\right)$ berpengaruh secara signifikan terhadap keputusan pembelian. Hal ini sesuai dengan penelitian Claypool et al. (2004) dan Ade (2016) bahwa personal relevance berpengaruh tehadap perubahan perilaku seseorang dalam mengambil keputusan. Variable interactive $\left(\mathrm{X}_{2}\right)$ menyatakan bahwa tidak ada pengaruh terhadap keputusan pembelian hasil ini berbeda dengan penelitian Ade (2016) yang menyatakan bahwa interactive berpengaruh terhadap keputusan pembelian. Pada variabel message (X3) menunjukkan hasil yang signifikan tetapi menandakan hasil yang negatif dikarenakan pesan yang disampaikan Kopi Kenangan tidak menunjukkan hasil yang positif mengingat nama Kopi Kenangan untuk usia muda dan bagi usia di atas 30 kurang sesuai. Hal ini berbeda dengan penelitian Ade (2016) serta Pradana dan Handrito (2013) tentang pengaruh iklan terhadap keputusan pembelian. Sedangkan untuk analisis simultan seperti tabel di bawah ini:

Tabel 5. ANOVA

\begin{tabular}{|c|c|c|c|c|c|c|}
\hline Model & & $\begin{array}{l}\text { Sum of } \\
\text { Squares }\end{array}$ & df & $\begin{array}{l}\text { Mean } \\
\text { Square }\end{array}$ & $\mathbf{F}$ & Sig. \\
\hline \multirow[t]{3}{*}{1} & Regression & 160.217 & 3 & 53.406 & 3170.006 & $.000^{\mathrm{a}}$ \\
\hline & Residual & 2.712 & 161 & .017 & & \\
\hline & Total & 162.929 & 164 & & & \\
\hline
\end{tabular}

a. Predictors: (Constant), Message, Interactive, Personal Relevance

Dependent Variable: Keputusan Pembelian

Tabel di atas menunjukkan bahwa variable personal relevance $\left(\mathrm{X}_{1}\right)$, interactive $\left(\mathrm{X}_{2}\right)$ dan message $\left(\mathrm{X}_{3}\right)$ berpengaruh positif terhadap keputusan pembelian.

\section{KESIMPULAN DAN SARAN}

Dari hasil penelitian pengaruh promosi online terhadap keputusan pembelian Kopi Kenangan dijelaskan sebagai: (1) Berdasarkan tanggapan responden, secara keseluruhan pelaksanaan promosi online pada media sosial Kopi Kenangan sangat baik, (2) Berdasarkan 
tanggapan responden, secara keseluruhan keputusan pembelian Kopi Kenangan sangat baik, (3) Variabel personal relevance berpengaruh terhadap keputusan pembelian pada Kopi Kenangan, (4) Variabel interactivity tidak memberikan pengaruh terhadap keputusan pembelian Kopi Kenangan, (5) Variabel message memiliki pengaruh terhadap keputusan pembelian Kopi Kenangan., (6) Pada ketiga variabel bebas, yang paling dominan mempengaruhi perilaku pengambilan keputusan konsumen yakni variabel personal relevance. Peneliti selanjutnya dapat diteliti lebih luasa lagi dengan menambah beberapa variabel yang belum diteliti sebelumnya.

\section{REFERENSI}

Ade Raisha Nurgayatri. (2016) Pengaruh Promosi Online pada Media Sosial terhadap Keputusan Pembelian Konsumen Brand Elmeira. Jurnal Manajemen Indonesia, 3 (3).

Alfirahmi. (2019). Fenomena Kopi Kekinian di Era 4.0. Jurnal Lugas, 3(1), 24-32.

Ana Ramadhayanti. (2019). Analisis Gaya Komunikasi Pemasaran Online dan Pengembangan Infrastruktur E-Commerce terhadap Keputusan Pembelian. Jurnal Manajemen Indonesia.

Arwiedya, Y. (2011). Keputusan Membeli Secara Online dan Faktor-Faktor yang Mempengaruhinya. Jurnal Teknologi Informasi Dinamik.

Asosiasi Penyelenggara Jasa Internet Indonesia (APJII). (2018). Hasil Survei 2018 Asosiasi Penyelenggara Jasa Internet Indonesia (APJII). Diakses 25 Desember 2019.

Ferdinand, A. (2007). Manajemen Pemasaran (I). Jakarta: Erlangga.

http://library.binus.ac.id/eColls/eThesisdoc/Bab2HTML/Bab209218/body.html

Jamaludin, A. (2015). Pengaruh Promosi Online dan Persepsi Harga terhadap Keputusan Pembeli (Survei pada Pelanggan Aryka Shop di Kota Malang). Jurnal Administrasi Bisnis S1 Universitas Brawijaya.

Kotler, P., dan Keller, K. L. (2009). Manajemen Pemasaran Jilid 1. Jakarta.

Kottler, P., dan Armstrong, G. (2008). Prinsip-Prinsip Pemasaran (Edisi ke-12. Jilid ke-1). Jakarta: Erlangga.

Pratiwi, Y. R., dan Lubis, E. E. (2017). Pengaruh Word of Mouth Communication terhadap Keputusan Pembelian Konsumen pada Boardgame Lounge Smart Cafe Pekanbaru. Jurnal Online Mahasiswa Fakultas Ilmu Sosial dan Ilmu Politik Universitas Riau, 4 (1), $1-15$.

Musay, F. P. (2013). Pengaruh Brand Image terhadap Keputusan Pembelian. Jurnal Administrasi Bisnis S1 Universitas Brawijaya.

Rahayu, S. (2016). Pengaruh Komunikasi Pemasaran Terhadap Pengambilan Keputusan Pembelian Kartu AS Telkomsel Masyarakat Kota Makassar. Doctoral Dissertation, Universitas Islam Negeri Alauddin Makassar.

Sangadji, E. M. dan S. (2013). Perilaku Konsumen: Pendekatan Praktis Disertasi Himpunan Jurnal Penelitian. Penerbit Salemba.

Shewan, H. M., and Stokes, J. R. (2013). Review of Techniques to Manufacture MicroHydrogel Particles for The Food Industry and Their Applications. In Journal of Food Engineering.

Sejarah Kopi Kenangan https://id.wikipedia.org/wiki/Kopi_Kenangan 